\title{
Effects of Tianda 2116 Plant Growth Regulator on Growth and Yield of Winter Wheat (Triticum aestivum L.)
}

\author{
B. T. Manenji, H. Mushipe, I. Chagonda, M. T. Mabarani, M. Chandiposha \\ Department of Agronomy, Faculty of Natural Resources Management and Agriculture, Midlands State \\ University, Gweru, Zimbabwe \\ Email: jtmidzi@gmail.com
}

Received 28 May 2015; accepted 20 February 2016; published 23 February 2016

Copyright @ 2016 by authors and Scientific Research Publishing Inc.

This work is licensed under the Creative Commons Attribution International License (CC BY). http://creativecommons.org/licenses/by/4.0/

c) (i) Open Access

\section{Abstract}

To achieve optimum yield of wheat, supplementation of soil and foliar applied fertilizers with plant growth regulators is vital to assure effective assimilation of nutrients by plants. A trial was conducted at Gwebi Agricultural College Farm in Mashonaland West Province of Zimbabwe, during the $\mathbf{2 0 1 2}$ winter wheat season (May to August), to evaluate the effects of differing times of application of Tianda 2116 plant growth regulator on the growth and yield of wheat (variety SC Sekuru). The trial was laid out in a Randomized Complete Block Design with three replications. The treatments were: Tianda 2116 applied at the following weeks after planting (WAP): 2 WAP, 3 WAP, 4 WAP, 5 WAP, 6 WAP, 14 WAP and no Tianda 2116 applied (control). No significant differences ( $P>$ 0.05 ) were noted among treatments for mean number of tillers per plant and mean number of spikes per plant. Application of Tianda 2116 at 2 and 3 WAP delayed flowering and physiological maturity. Early application of Tianda 2116 increased the number of spikelets per spike, thousand grain weight and grain yield. Conclusively, Tianda 2116 applied 2 or 3 WAP is effective in reducing growth while enhancing yield parameters in wheat production.

\section{Keywords}

Tianda 2116, Plant Growth Regulator, Spike, Spikelets, Growth Parameters

\section{Introduction}

Food production remains dominated by cereals which make up around $50 \%$ of global food production [1]. Wheat (Triticum aestivum) is an important cereal, ranked as the second most important grain crop after maize [2] 
and is regarded as a strategic crop whose adequate reserves creates self-sufficiency and combat hunger [3]. Wheat grain contains approximately $70 \%$ carbohydrates, $11.5 \%$ protein, $2 \%$ fibre, $1.5 \%$ ash and $13 \%$ water [4]. Wheat can be processed into flour which is used in the manufacture of breakfast foods, alcohol, dextrose and as animal feed. The wheat straw provides valuable fodder and is also used for making baskets, hats, bedding in fowl runs and as substrate e.g. in mushroom production.

Despite its importance, wheat production in Zimbabwe has been reported to be on the decline [5]. Zimbabwe at its peak (1990 and 2001) produced 325,000 tonnes of wheat [1] with an average yield per hectare of 7400 and $7100 \mathrm{~kg}$ respectively. Lowest annual yields were recorded in 2009 where only 12,000 tonnes were achieved from an area of 1800 ha planted [1]. The decline in wheat volumes is a result of a number of constraints including moisture stress at critical growth stages which results in stunted growth, reduced tillering and poor grain set [4]. Concomitant with poor rainfall, a major constraint to crop production including wheat production, is poor soil fertility [6] [7]. Poor soil fertility, especially nitrogen, phosphorous and potassium deficiency, reduces the activity of enzymes and also reduces the crop's resistance to adverse changes to the environment thereby forcing plants into reproduction before vegetative growth completes [6].

In order to curb the challenge of soil fertility, the majority of commercial and communal wheat farmers use soil applied fertilizers, both organic and inorganic to enhance growth and yield. However, soil applied fertilizers are often associated with ephemeral nutrient deficiency which results in deficiencies of nutrients during periods of critical demands such as reproductive stage as a result of limitations in uptake or restrictions in nutrient delivery [8]. There is need therefore to use foliar applied plant growth regulators as a supplement to soil applied fertilizers to enhance enzyme activities in the plants and address ephemeral nutrient deficiencies at critical growth stages [9].

In order to enhance wheat yield farmers could use a newly introduced Chinese plant growth regulator, Tianda 2116. This plant growth regulators has been recently reported to enhance growth and yield of wheat [10]-[12]. Research done on wheat in China show that Tianda 2116 plant growth regulator increases the chlorophyll content in wheat leaves [13]. Chlorophyll is essential in photosynthesis for the synthesis of photo-assimilates essential for grain filling during the reproductive stage of wheat development [13]. Tianda 2116 has also been proven to reduce electrolyte leakage in all photosynthesizing plant parts especially the head and the flag leaf [14] and this helps to keep up tugor pressure and prevent plasmolysis by creating a hypotonic environment in plant cells. Tianda 2116 plays an important role in improving grain quality and strengthening photosynthetic rate of grain filling period [10]. In Zimbabwe not much research has been done to evaluate effects of the newly introduced plant growth regulator, Tianda 2116 on growth and yield of wheat. This research therefore aims to determine the effects of differing application time of Tianda 2116 on growth and yield of wheat.

\section{Materials and Methods}

The research was conducted at Gwebi Agricultural College farm (17 40'60"S, 3052'0"E and $1.438 \mathrm{~m} \cdot \mathrm{asl})$ in Zimbabwe agro-ecological region IIb. Some of the pre-sowing soil physical and chemical properties at the experimental site are as shown in Table 1. The experiment was laid in a Randomized Complete Block Design (RCBD) with 7 treatments replicated three times (Table 2).

Conventional tillage was done using a tractor and a torpedo tractor drawn plough to invert the soil and bury some of the debris from the previous crop and control weeds. This was followed by secondary tillage using a disc harrow to prepare the seedbed. Wheat seeds of variety SC Sekuru, were drilled in rows which had an interow spacing of $0.25 \mathrm{~m}$ at a seed rate of $100 \mathrm{~kg} \cdot \mathrm{ha}^{-1}$. Compound D fertilizer $\left(\mathrm{N}_{7}: \mathrm{P}_{14}: \mathrm{K}_{7}\right)$ was drilled in each plot at a rate of $400 \mathrm{~kg} \cdot \mathrm{ha}^{-1}$ at planting, while Ammonium nitrate $(34.5 \% \mathrm{~N})$ was applied four weeks after planting at a rate of $400 \mathrm{~kg} \cdot \mathrm{ha}^{-1}$. Weeding was done manually by hand pulling in between rows. Frequent scouting of pests and diseases was done. Leaf rust was successfully controlled using Shavit (Triademenol 25\% EC active ingredient) at a rate of $125 \mathrm{ml} \cdot \mathrm{ha}^{-1}$. The plant growth regulator (Tianda 2116) was applied at a rate of $375 \mathrm{~g} \cdot \mathrm{ha}^{-1} \mathrm{us}^{-}$ ing a knapsack sprayer at different times according to the respective treatments (Table 2). The powder was mixed with 600 liters of water. The resultant solution contained 1\% Chitosan concentration. The solution was then sprayed on wheat canopy at an elevation of less than $30 \mathrm{~cm}$ above the wheat canopy. Hooded sprays were used to avoid spray drift onto adjacent or neighboring plots.

An automatic weather station located some 120 metres from the experimental site recorded rainfall (mm), maximum and minimum air temperature $\left({ }^{\circ} \mathrm{C}\right)$, solar radiation $\left(\mathrm{MJ} \cdot \mathrm{m}^{-2} \cdot \mathrm{d}^{-1}\right)$, reference evapotranspiration $(\mathrm{mm})$ and vapour pressure deficit VPD (KPa) each day during the experiment (Table 3). Very few rains were received 
Table 1. Physical and chemical properties of the soil (0 - $20 \mathrm{~cm}$ depth) at Gwebi Agricultural College.

\begin{tabular}{|c|c|}
\hline Soil properties & Value \\
\hline $\mathrm{pH}\left(\mathrm{H}_{2} \mathrm{O}\right)$ & 6.13 \\
\hline $\mathrm{pH}(\mathrm{kCl})$ & 4.80 \\
\hline \multicolumn{2}{|l|}{ Particle size (\%) } \\
\hline Clay & 72.5 \\
\hline Silt & 18.5 \\
\hline Sand & 9.0 \\
\hline $\mathrm{CEC}\left(\mathrm{cmol} \cdot \mathrm{kg}^{-1}\right)$ & 17.20 \\
\hline Carbon (\%) & 1.68 \\
\hline Phosphorus $\left(\mathrm{mg} \cdot \mathrm{kg}^{-1}\right)$ & 2.00 \\
\hline \multicolumn{2}{|c|}{ Exchangeable cations $\left(\mathrm{cmol} \cdot \mathrm{kg}^{-1}\right)$} \\
\hline $\mathrm{Na}$ & 0.03 \\
\hline $\mathrm{K}$ & 0.18 \\
\hline $\mathrm{Ca}$ & 3.99 \\
\hline $\mathrm{Mg}$ & 2.15 \\
\hline
\end{tabular}

Table 2. Time of application of Tianda 2116 in wheat.

\begin{tabular}{cc}
\hline Treatment & Time of Tianda 2116 application \\
\hline T1 & Two weeks after planting (2 W.A.P) \\
T2 & Three weeks after planting (3 W.A.P) \\
T3 & Four weeks after planting (4 W.A.P) \\
T4 & Five weeks after planting (5 W.A.P) \\
T5 & Six weeks after planting (6 W.A.P) \\
T6 & Fourteen weeks after planting (14 WAP) \\
T7 (control) & No Tianda 2116 applied \\
\hline
\end{tabular}

Table 3. Summary of weather data at Gwebi Agricultural College during the winter (2012) cropping season.

\begin{tabular}{cccccc}
\hline & Mean temperature $\left({ }^{\circ} \mathbf{C}\right)$ & Total rainfall $(\mathbf{m m})$ & Total epan $(\mathbf{m m})$ & Solar radiation $\left(\mathbf{M J}^{\prime} \cdot \mathbf{m}^{-\mathbf{1}} \cdot \mathbf{d}^{-\mathbf{1}}\right)$ & Mean VPD $(\mathbf{K p a})$ \\
\hline \multirow{2}{*}{ May } & 23.0 & 0.0 & 99.4 & 15.5 & 1.0 \\
June & 18.4 & 0.0 & 89.1 & 13.3 & 1.3 \\
July & 16.8 & 0.0 & 85.4 & 12.7 & 0.9 \\
August & 19.1 & 40.9 & 109.8 & 17.1 & 1.3 \\
Mean & 19.3 & 10.2 & 95.9 & 14.7 & 1.1 \\
\hline
\end{tabular}

in the growing season as this was winter time which is characterized by cold dry conditions. Frequencies of irrigation were based on the irrigation schedule designed by MacRoberts (1993) in [15]. The total amount of irrigation water applied at the experimental fields for the duration of the experiment was $550 \mathrm{~mm}$.

The data that was collected include plant height, days to flowering, days to physiological maturity, number of tillers per plant, number of spikes, thousand grain weight and grain yield. Analysis of Variance was performed 
using GenStat $14^{\text {th }}$ edition. Significant differences between treatment means were determined at $5 \%$ level using the least significant differences (LSD) test.

\section{Results and Discussion}

\subsection{Effects of Differing Application Time of Tianda 2116 on Plant Height of Wheat}

Early application of Tianda 2116 at 2 and 3 WAP resulted in reduction of wheat plant height (Figure 1). This was mainly due to the effect of Chitosan (active ingredient of Tianda 2116), which retards the lengthening of basal internodes of wheat especially when it is applied in the early vegetative growth [16]. The results were in line with studies conducted by [17] on the application of Chitosan in wheat plants. He also observed that early application (7 - 21 days after emergence) of Chitosan resulted in short wheat straw as compared to no or late application. He also noted that seed soaking in Chitosan solution before planting reduced plant height. However, [18] found contradicting observations that, foliar application of oligomeric Chitosan at any growth stage did not affect the height of rice and soybean plants.

\subsection{Effects of Differing Application Time of Tianda 2116 on Number of Days to Flowering}

Early application of Tianda 2116 at 2 WAP, 3 WAP and 4 WAP delayed flowering of wheat plants (Table 4). This may be because of elevated nitrogen levels during the early stages of growth promoting rank growth there-

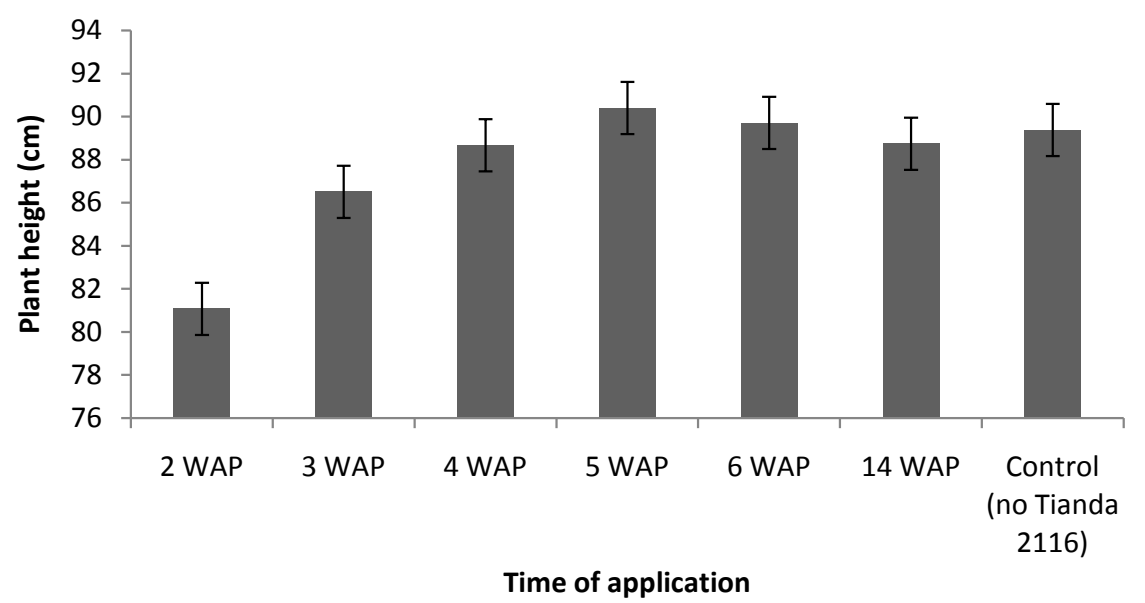

Figure 1. Effects of differing application time of Tianda 2116 on wheat plant height.

Table 4. Effects of differing time of Tianda 2116 application on number of days to flowering and number of days to physiological maturity.

\begin{tabular}{|ccc|}
\hline Treatment (Time of Tianda 2116 application) & Number of days to flowering & Number of days to physiological maturity \\
\hline 2WAP & $9.46^{\mathrm{b}}(89.50)$ & $11.55^{\mathrm{b}}(133.40)$ \\
3WAP & $9.44^{\mathrm{b}}(89.11)$ & $11.50^{\mathrm{ab}}(132.25)$ \\
4WAP & $9.41^{\mathrm{ab}}(88.55)$ & $11.44^{\mathrm{a}}(130.87)$ \\
5WAP & $9.35^{\mathrm{a}}(87.42)$ & $11.44^{\mathrm{a}}(130.87)$ \\
6WAP & $9.35^{\mathrm{a}}(87.42)$ & $11.41^{\mathrm{a}}(130.19)$ \\
14WAP & $9.34^{\mathrm{a}}(87.24)$ & $11.45^{\mathrm{a}}(131.10)$ \\
Control (No Tianda 2116 application ) & $9.34^{\mathrm{a}}(87.24)$ & $11.42^{\mathrm{a}}(130.42)$ \\
LSD & 0.07 & 0.09 \\
$P$ value & $<0.05$ & $<0.05$ \\
\hline
\end{tabular}

Numbers in brackets represent the actual non transformed figures. Means in the same column followed by the same letter are not significantly different $(P>0.05)$. 
by delaying flowering as the straw continues to grow. Flood and Halloran (1986) noted that wheat types which are responsive to vernalization flower after exposure and completion of a cold period. The double ridge stage is not reached until the chilling or vernalization requirements are met thus the vegetative phase is prolonged generating an increased number of leaves in the main shoot. However, [17] discovered that the effectiveness of low temperatures to initiate or accomplish vernalization decreases with early application of oligomeric Chitosan, as a result the vegetative phase is prolonged thereby delaying flowering. [19] also pointed out that vernalization occurs at three stages of the growing cycle of wheat plants: during germination, during vegetative plant growth and during grain filling. Early application of Chitosan therefore forces wheat plant to delay vernalization and flowering at the pre-determined vegetative growth stage expected of the variety Ceteris paribus. The effectiveness of low temperatures to achieve vernalization decreases with reduced nutrient availability, and increasing plant age [20].

\subsection{Effects of Differing Application Time of Tianda 2116 on the Mean Number of Days to Physiological Maturity}

Delaying application of Tianda 2116 from 3 WAP to 14 WAP significantly $(p<0.05)$ reduced the time taken to physiological maturity (Table 4). [21] noted that early application of plant growth regulators in cereals primarily promotes leaf area expansion, stimulates the photosynthetic activity of the leaf as well as delaying canopy senescence. Studies conducted by [14] showed that early application of Tianda 2116 slowly increased malondialdehyde (MDA) (main product of membrane lipid peroxide) content which intend reduces senescence flag leaf and peduncle, increasing physiological maturity of wheat.

\subsection{Effects of Differing Application Time of Tianda 2116 on Number of Tillers, Spikes per and Spikelets per Spike}

There was no significant difference $(p>0.05)$ on the effects of differing application time of Tianda 2116 on number of tillers per plant and number of spikes per plant (Table 5). All treatments were comparable to no application of Tianda 2116 on number of tillers and spikes per plant. The possible reason could be that the number of tillers and spikes per plant is mainly controlled by the genetic makeup of the plant. Although other factors like population density, sowing date, and the availability of water and nutrients also plays a role in determining the number of tillers per plant [22]. Number of spikes produced per plant could be a function of seed variety potential, soil nutrient availability, moisture availability, planting density and relatively lower temperatures to stimulate spike initiation. Early application of Tianda 2116 at 2 and 3 WAP resulted in an increase of spikelets per spike. The number of spikelets per spike is determined at about 10 days before flowering [23]. According to [24],

Table 5. Effects of differing time of Tianda 2116 application on number of tillers per plant, number of spikes per plant, number of spikelets per spike, thousand grain weight and grain yield of wheat.

\begin{tabular}{|c|c|c|c|c|c|}
\hline $\begin{array}{c}\text { Treatment } \\
\text { (Time of Tianda } 2116 \text { application) }\end{array}$ & $\begin{array}{l}\text { Number of } \\
\text { tillers/plant }\end{array}$ & $\begin{array}{l}\text { Number of } \\
\text { spikes/plant }\end{array}$ & $\begin{array}{c}\text { Number of } \\
\text { spikelets/spike }\end{array}$ & $\begin{array}{l}\text { Thousand } \\
\text { grain weight(g) }\end{array}$ & $\begin{array}{c}\text { Grain } \\
\text { yield (t/ha) }\end{array}$ \\
\hline 2WAP & $2.48(6.15)$ & $2.34(5.48)$ & $6.49^{\mathrm{d}}(42.12)$ & $46.03^{c}$ & $4.71^{\mathrm{e}}$ \\
\hline 3WAP & $2.47(6.10)$ & $2.27(5.15)$ & $6.57^{\mathrm{d}}(43.16)$ & $46.17^{c}$ & $4.75^{\mathrm{e}}$ \\
\hline 4WAP & $2.60(6.76)$ & $2.27(5.15)$ & $6.23^{\mathrm{c}}(38.81)$ & $41.87^{\mathrm{b}}$ & $4.19^{\mathrm{d}}$ \\
\hline 5WAP & $2.48(6.15)$ & $2.27(5.15)$ & $5.93^{\mathrm{b}}(35.16)$ & $40.20^{\mathrm{a}}$ & $4.02^{\mathrm{c}}$ \\
\hline 6WAP & $2.55(6.50)$ & $2.27(5.15)$ & $5.61^{\mathrm{a}}(31.47)$ & $40.33^{\mathrm{a}}$ & $3.80^{\mathrm{b}}$ \\
\hline 14WAP & $2.47(6.10)$ & $2.20(4.84)$ & $5.55^{\mathrm{a}}(30.80)$ & $38.43^{\mathrm{a}}$ & $3.66^{\mathrm{a}}$ \\
\hline Control (No Tianda application) & $2.54(6.45)$ & $2.34(5.48)$ & $5.61^{\mathrm{a}}(31.47)$ & $39.63^{\mathrm{a}}$ & $3.73^{\mathrm{a}}$ \\
\hline LSD & & & 0.21 & 2.22 & 0.11 \\
\hline$P$ value & Not significant & Not Significant & $<0.05$ & $<0.05$ & $<0.05$ \\
\hline
\end{tabular}

Numbers in brackets represent the actual non transformed figures. Means in the same column followed by the same letter are not significantly different $(P>0.05)$. 
there is a very close correlation between number of spikelets per spike and the Chitosan content in leaf blades during the first four week period before flowering. [25] observed that degeneration of differentiated spikelets occur during the spikelet-formation stage i.e. at the stage of reduction division of pollen mother cells. Differentiation and degeneration of spikelets is a result of sensitivity to environmental conditions especially nitrogen supply and solar radiation with the most critical period for nitrogen supply being 30 - 32 days before flowering. Differentiation of spikelets is strongly promoted by nitrogen and Chitosan supply while spikelet degeneration is prevented by an efficient carbohydrate supply. The final number of spikelets usually is closely correlated with the amount of total nitrogen and plant growth regulators absorbed up to the flowering stage [26]. Thus, Tianda 2116 applied at the earlier stages of growth before flowering is effective in increasing the number of spikelets per spikes. This could be attributed to the fact that early application of Tianda 2116 could also translate into higher concentration of the growth regulator on a smaller leaf area as compared to later/subsequent applications on well established crop canopy.

\subsection{Effects of Differing Application Time of Tianda 2116 on Thousand Grain Weight of Wheat}

Early application of Tianda 2116 at 2 and 3 WAP increased thousand grain weight of wheat (Table 5). There was more grain filling of wheat grains with early application of Tianda 2116. Perhaps this could be a result of extended physiological maturity with early application of Tianda 2116 evidenced in this study. Extension of physiological maturity is synonymous with high uptake of photosynthetically active radiation intercepted by the leaves resulting in an increase of carbohydrates which are channeled to the sinks, which in this case are the wheat grains. In addition, this study also revealed that early application of Tianda 2116 resulted in delay of flowering, therefore more vegetative growth. Increased vegetative growth with early application of the plant growth regulator may have elevated the strength of the source (leaves). If the strength of the source is high, there is high likelihood of channeling of assimilates to the grains.

\subsection{Effects of Differing Application Time of Tianda 2116 on Wheat Grain Yield ( $t / h a)$}

Application of Tianda 2116 at 2 and 3 WAP resulted in high wheat grain yield (Table 5). This could be as a result of high number spikelets per spike and thousand grain weight observed in this study. High number of spikelets per spike increased the number of grains while thousand grain weight elevated the mass per individual grain, thus both factors contributing to grain yield. The grain yield trend observed in this study was similar to that obtained by Fengxia et al., (2011) who observed a significant grain yield increase of $10.5 \%-12.6 \%$ in treatments were Tianda 2116 was applied 18 - 25 days after planting.

\section{Conclusion}

From this research it can be concluded that early application of Tianda 2116 growth regulator at 2 and 3 WAP resulted in reduced plant growth, however increased physiological maturity, number of days to flowering, number of spikelets per spike, thousand grain weight and grain yield of wheat.

\section{Acknowledgements}

The authors would like to give sincere gratitude to the Department of Research and Specialist Services (DR \& SS) for availing the resources to carry out this research. Also the acknowledgement of research assistance provided by Mr Nyambo and Mr Petro from Department of Research and Specialists Services.

\section{References}

[1] United States Department of Agriculture (USDA) (2013) Zimbabwe Wheat Production by Year.

[2] Theron, D. (2010) Land Reform in Zimbabwe: Impact on Food Production Self-Sufficiency. CFU Zimbabwe Report. Zimbabwe, CFU Publishers.

[3] Seed Co. (2007) www.seedcogroup.com/country/zimwheat.html accessed 01/11/14

[4] Raemaekers, R.H. (2001) Crop Production in Tropical Africa. DGIC, Brussels, Belgium

[5] Mangosho, E., Kananga, G. and Mupambwa, H. (2008) Chemical Controls in Some Weed Crops. Department of Re- 
search and Specialist Services, Agronomy Research Institute, Zimbabwe.

[6] Nyakanda, B. (2004) Pest and Diseases That Affect Wheat in Zimbabwe. Seed Co L.T.D, Zimbabwe.

[7] Sanchez, P.A. (2002) Soil Fertility and Hunger in Africa. Agricultural Science, 295, 2019-2020

[8] Schonherr, N. (2006) Fundamentals of Foliar Fertilizers and Nutrient Analysis. Michigan State University, Bolia.

[9] Nyomora, A.O., Veitia, L., Wade, J. and Maleza, H. (2002) Soil Testing and Crop Specific Recommendations. University of Zimbabwe, Harare.

[10] Yang, W.-P., Hu, X.-Q. and Wu, D.-F. (2006) Effect of Tianda-2116 on Matter Distribution and Yield of Winter Wheat. Journal of Henan Agricultural Sciences.

[11] Yang, W.-P. and Hu, X.-Q. (2010) Effects of Foliage Spray with Tianda-2116, a Growing Regulator, on Spike Character and Yield of Xinmai 18 (A Winter Wheat Variety). Guizhou Agricultural Sciences.

[12] Zhang, B.J., Yang, W.P., Liang, M.Q. and Luo, H. (2003) Regulating Effect of Tianda-2116 on Growth, Development, Yield and Quality of Winter Wheat. Acta Tritical Crops.

[13] Mrinal, B.A. and Peter, J.G. (2010) Thylakoid-Localized FK506-Binding Protein in Wheat May Be Linked to Chloroplast Biogenesis. Plant Physiology and Biochemistry, 48, 655-662. http://dx.doi.org/10.1016/j.plaphy.2010.05.002

[14] Li, F.X., Ma, H.Q., Du, H.W., Lin, Y.Z., Nie, H.C. and Wang, F.H. (2011) Role of “Tianda 2116” in Enhancing Resistance to Chilling Injury in Winter Wheat. Crop Research Institute, Shandong Academy of Agricultural Sciences, Jinan.

[15] MacRoberts, J.F. and Savage, M.J. (1998) The Use of Crop Simulation Model for Planning Wheat Irrigation in Zimbabwe. In: Tsuji, G.Y., Hoogenboom, G. and Thornton, P.K., Eds., Understanding Options for Agricultural Production, Kluwer Academic, Dordrecht, 205-220.

[16] China Papers (2010) Influence of Tianda - 2116 on the Growth and Development of Vine. Posted on March 27, 2010. http://mt.china-papers.com/1/?p=172667

[17] Boonlertnirum, S., Boonraung, C. and Suvanasara, R. (2008) Application of Chitosan in Rice, Wheat, Maize and Soyabean Production. Faculty of Agricultural Technology and Agro-Industry, Rajamangala University of Technology Suvarnabhumi, Thailand.

[18] Khan, W., Prithiviraj, B. and Smith, D.L. (2002) Effect of Foliar Application of Chitin and Chitosan Oligosaccharide on Photosynthesis of Maize and Soybean. Photosynthetica, 40, 621-624. http://dx.doi.org/10.1023/A:1024320606812

[19] Flood, R.G. and Halloran, G.M. (1986) Genetics and Physiology of Vernalization Response in Wheat. Advanced Agronomy, 39, 87-125. http://dx.doi.org/10.1016/S0065-2113(08)60466-6

[20] Chujo, H., Kriederman, C. and Leopold, F. (1996) The Effect of Diurnal Temperature Variation on Vernalization in Wheat. Crop Science Society of Japan, 35, 187-194.

[21] Murata, Y. (2006) Photosynthesis, Respiration and Nitrogen Response. In: The Mineral Nutrition of the Rice Plant, Johns Hopkins Press, Baltimore, 385-400.

[22] Duggan, B.L., Richards, R.A., van Herwaarden, A.F. and Fettell, N.A. (2005) Agronomic Evaluation of a Tiller Inhibition Gene (TIN) in Wheat. Effect on Yield, Yield Components, and Grain Protein. Australian Journal of Agricultural Research, 56, 169-178. http://dx.doi.org/10.1071/AR04152

[23] Griffith, W.K., Teel, M.R. and Parker, H.E. (2007) Influence of Nitrogen and Potassium and Chitosan on the Yield and Chemical Composition of Orchard Grass. Agronomy Journal, 56, 473-475. http://dx.doi.org/10.2134/agronj1964.00021962005600050008x

[24] Kumura, A. (2002) Studies on the Production and Behavior of Carbohydrates in Rice Plant. Japanese Journal of Crop Science, 24, 324-330.

[25] Matsushima, S. (2000) Analysis of Developmental Factors Determining Yield and Yield-Prediction in Lowland Rice. Bulletin of the National Institute of Agricultural Sciences in Japan, 5, 1-271.

[26] Wada, A.A. and McKell, C.M. (2010) Effect of Nitrogen Fertilization on the Carbohydrate Content of Coastal Bermuda Grass (Cynodon dactylon). Agronomy Journal, 58, 60-64. 